\title{
PENGARUH LAYANAN BIMBINGAN KELOMPOK TEKNIK DISKUSI TERHADAP KEBIASAAN MENONTON FILM SINETRON DI SMP NEGERI I BATANG KUIS
}

\author{
Muhammad Khuzairi Batubara ${ }^{1}$, Nasrun ${ }^{2}$ \\ Program Studi Bimbingan dan Konseling, FIP-Universitas Negeri Medan ${ }^{1,2}$
}

\begin{abstract}
Abstrak
Penelitian ini bertujuan untuk mengetahui pengaruh bimbingan kelompok teknik diskusi terhadap mengurangi kebiasaan menonton film sinetron khususnya yang bertema percintaan remaja dan bertendensi negatif di kelas VIII SMP Negeri I Batang Kuis. Jenis penelitian ini adalah penelitian eksperimen semu (quasy experiment). Dengan desain pre-test dan post-test. Subjek penelitian adalah siswa kelas VIII-6 yang berjumlah 9 orang. Instrumen pengumpulan data dengan menggunakan angket untuk mengetahui kebiasaan menonton film sinetron khususnya tentang tema percintaan remaja dan bertendensi negatif pada siswa. Angket diuji cobakan dan dianalisis untuk mendapatkan angket yang valid dan reliabel. Teknik analisis data menggunakan uji $t$. Hasil penelitian menunjukkan bahwa pelaksanaan bimbingan kelompok teknik diskusi berpengaruh terhadap mengurangi kebiasaan menonton film sinetron pada siswa di SMP Negeri I Batang Kuis. Hal ini tergambar dengan hasil penelitian menunjukkan bahwa $t_{\text {hitung }}=15,53$ untuk responden sebanyak 9 orang diperoleh $t_{\text {tabel }} 2,306$, tampak bahwa $t_{\text {hitung }}>t_{\text {tabel. }}$. Maka hipotesa alternatif yang diajukan diterima pada signifikan taraf $0,05 \%$. Artinya ada pengaruh yang signifikan antara pelaksanaan bimbingan kelompok teknik Diskusi terhadap mengurangi kebiasaan menonton film sinetron khususnya tentang tema percintaan remaja dan bertendensi negatif di kelas VIII SMP Negeri I Batang Kuis
\end{abstract}

Kata Kunci: Bimbingan Kelompok; Teknik Diskusi; Kebiasaan Menonton Film Sinetron

PENDAHULUAN

Masa remaja adalah suatu

tahap kehidupan yang bersifat

peralihan dan tidak mantap. Menurut

Piaget (dalam Hurlock, 1999: 118)

secara psikologis masa remaja

merupakan usia dimana individu

berintegrasi dengan masyarakat.

Lazimnya masa remaja dimulai pada

saat anak matang secara seksual dan

berakhir sampai ia matang secara

hukum.
Menurut Havigurst (dalam

Hurlock, 1999), setiap tahap perkembangan memiliki tugas-tugas perkembangan. Tugas-tugas perkembangan memiliki peranan penting untuk menentukan arah perkembangan yang normal. Remaja diharapkan untuk dapat mencapai kemandirian emosional dari orang tua dan orang-orang dewasa lainnya. Pada masa awal, remaja masih belum 
mampu untuk mengatasi masalahnya sendiri, namun pada usia enam belasan remaja sudah mulai menunjukkan kemandirian, khususnya secara emosional (Sarwono, 2006)

Menurut Hana dan Seto Mulyadi (Farindra, 2008) mengungkapkan sinetron memberi pengaruh besar terhadap merosotnya moral dan akidah pelajar Indonesia, sedangkan tayangan yang mengandung edukasi hanya $0,07 \%$. Didukung oleh Poltak Tampubolon (Pikiran Rakyat, 14 April 2009) mengungkapkan tujuan dari pembuatan sinetron adalah hanya untuk komersial semata sehingga menurunkan kualitas cerita yang akhirnya membuat sinetron menjadi tidak lagi mendidik tetapi hanya menyajikan hal-hal yang sifatnya menghibur. Sebagian besar sinetron pada umumnya bercerita seputar percintaan, kekayaan, dan adanya unsur kekerasan. Namun tidak semua sinetron bermutu rendah, ada sinetron yang mengedepankan unsur budaya dan pendidikan misalnya sinetron yang menceritakan kehidupan keluarga sederhana.
Tidak dipungkiri, dengan adanya media massa televisi, banyak sekali manfaat yang bisa kita ambil. Dimana kita akan dengan cepat memperoleh informasi-informasi terbaru yang terjadi dimanapun dan belahan dunia manapun. Dengan adanya televisi akan mempermudah suatu perusahaan atau badan usaha untuk mempromosikan produkproduknya, sehingga konsumen mengetahui dan dengan mudah mencari produk, serta masih banyak lagi keuntungan-keuntungan yang kita peroleh dengan adanya media televisi.

Berdasarkan permasalahan yang telah dipaparkan pada masa remaja mereka cenderung selalu ingin mencoba sesuatu yang baru, kalau sudah mencoba, meniru lama kelamaan mereka anggap sebagai hal biasa, dan bisa saja merugikan kehidupan selanjutnya. Suatu upaya yang dapat dilakukan untuk membantu siswa dalam mengurangi kebiasaan menonton film sinetron adalah dengan menggunakan layanan bimbingan kelompok. Layanan ini dapat membantu siswa untuk berfikir secara rasional. Pada kenyataannya, proses dan model yang digunakan 
saat ini dalam layanan bimbingan konseling di sekolah belum efektif dalam membantu siswa.

\section{KAJIAN PUSTAKA}

Berdasarkan pengamatan dan wawancara penulis pada saat PPLT di SMP Negeri 1 Batang Kuis pada tanggal 20 Agustus - 23 November 2015 , hal ini menunjukkan bahwa hasilnya memang kebanyakan siswa sangatlah jarang sekali tertinggal dengan tayangnya sinetron-sinetron tersebut.

Guru bimbingan konseling memiliki peranan penting dalam membantu siswa menyelesaikan masalah-masalah yang dihadapi siswa, termasuk masalah kebiasaan menoton sinetron salah satunya sinetron yang paling Hits dikalangan remaja saat ini yaitu Sinetron khususnya tentang tema percintaan remaja dan bertendensi negatif. Dalam menangani ini, guru bimbingan konseling memberikan layanan bimbingan kelompok untuk membantu siswa menyelesaikan masalahnya.

Bimbingan kelompok ialah bantuan yang diberikan oleh seorang konselor kepada klien (anggota kelompok) secara berkelompok yang memanfaatkan dinamika kelompok yang membahas permasalahan umum yang relatif sama antara siswa/konseli, yang membahas permasalahan secara bersama-samaa untuk membantu siswa memecahkan masalahnya dan mengembangkan pengetahuan dan kemandirian siswa Syaodih (dkk) dalam Tono Sumartono (1992: mengemukakan pengertian kebiasaan sebagai cara individu bertindak yang sifatnya relatif menetap, seragam dan otomatis untuk masa tertentu. Menonton adalah melihat pertunjukan, gambar hidup dan sebagainya (Poerwadaminta,1998 :108). Sedangkan pengertian menonton menurut Sardji (1991 dalam Naratama, 2004:71) adalah suatu proses yang disadari atau tidak disadari dimana menonton diletakan pada alam yang samar yang dihadapkan pada tumpuan cahaya dan membantu menghasilkan ilusi diatas layar yang akan menimbulkan emosi, pikiran dan perhatian manusia yang dipengaruhi tayangan-tayangan yang ditonton.

Menurut Arswendo (dalam Ardlz: 2008) mengemukakan 
sinetron adalah sandiwara Melalui layanan bimbingan bersambung yang disiarkan oleh stasiun televisi. Judul-judul sinetron diantaranya adalan Ganteng Ganteng Serigala , Anak Jalanan, dan sinetron lainyang bertemakan percintaan kalangan Remaja, dll. Dari beberapa paparan kebiasaan dalam penelitian kebiasaan suatu perilaku manusia yang menetap, berlangsung secara otomatis. Kebiasaan merupakan hasil pelaziman yang berlangsung pada waktu yang lama atau sebagai reaksi khas yang diulangi seseorang berkali-kali. Sinetron adalah drama serial yang disiarkan ditelevisi dalam beberapa episode dan jenis alur tertentu yang penayangannya rutin.

Berdasarkan uraian, yang dimaksud dengan kebiasaan menonton tayangan sinetron khususnya tentang tema percintaan remaja dan bertendensi negatif dalam penelitian ialah suatu bentuk perilaku siswa dengan dikerjakan secara terus menerus relatif menetap dalam menonton siaran televisi yang mengandung kisah asmara remaja akan berdampak buruk bila ditiru yang disiarkan oleh stasiun televisi di Indonesia.

kelompok teknik diskusi memungkinkan sejumlah peserta didik secara bersama-sama membahas tentang kebiasaan menonton film sinetron khususnya tentang tema percintaan remaja dan bertendensi negatif. Dimana menonton film sinetron tersebut sudah menjadi kebiaasan siswa dan suatu keharusan yang tidak bisa ditinggalkan sehingga kegiatan belajar di rumah berkurang yang akan bisa berakibat buruk dari prilakunya dan menurunnya prestasi belajar siswa tersebut. Dengan diberikannya bimbingan kelompok teknik diskusi terhadap kebiasaan menonton sinetron khususnya tentang tema percintaan remaja dan bertendensi negatif akan sedikit berkurang dan akan mengutamakan belajarnya. Dengan demikian siswa dapat menyesuaikan tontonan, dan frekuensi jam dalam menonton.

Berdasarkan uraian diatas, hal ini sejalan dengan teori yang dikemukakan oleh Dudung (2005: 35) bahwasanya kebiasaan menonton film sinetron khususnya tentang tema percintaan remaja dan bertendensi negatif dengan prilaku yang menetap, 
berlangsung otomatis, pada waktu yang lama dan dilakukan berkali kali akan merubah aspek dalam diri seseorang, yaitu ; Aspek Moralitas ; Aspek Seksualitas ; Aspek Kekerasan ; Aspek Prilaku ; dan Aspek Bahasa yang tidak senonok akan merubah beberapa aspek-aspek dalam diri seseorang disekitarnya yang diakibatkan oleh kurang mampu bergaul dengan orang lain, pasif dalam bertindak, serta mudah menyerah.

\section{METODE PENELITIAN}

Jenis penelitian ini adalah jenis penelitian quasi experiment yaitu penelitian yang dimaksudkan untuk mengetahui ada tidaknya akibat dari suatu yang dikenakkan pada subjek yang diselidiki (Menanti, 2013: 60). Penelitian ini menggunakan pendekatan kuantitatif, yang banyak dituntut menggunakan angka, mulai dari pengumpulan data, penafsiran terhadap data tersebut, serta penampilan dari hasilnya. Desain yang akan digunakan dalam penelitian ini adalah disain Pre-test dan Post-test Group.

Pengumpulan data dilakukan melalui angket yang dibagikan kepada siswa. Adapun angket yang digunakan adalah berdasarkan skala Likert yang terdiri dari 4 pilihan yaitu sangat setuju, setuju, kurang setuju, tidak setuju.

Sebelum peneliti meneliti kelas VIII-6, maka terlebih dahulu untuk subjek uji coba atau kuesioner penelitian, peneliti mengambil subjek uji coba kelas VIII-8 SMP Negeri I Batang Kuis sebanyak 30 orang siswa, yang diperoleh berdasarkan hasil pertimbangan guru BK dengan peneliti bahwa kelas VIII-8 yang sesuai jadwalnya untuk dijadikan sebagai subjek uji coba. Setelah proses uji coba angket, maka pengisian skala kebiasaan menonton film sinetron khususnya tentang tema percintaan remaja dan bertendensi negatif dalam bentuk skala Likert subjek yang diambil adalah siswa Kelas VIII-6 SMP Negeri I Batang Kuis yang tergolong mempunyai kebiasaan menonon film sinetron khususnya tentang tema percintaan remaja dan bertendensi negatif yang termasuk tinggi, sedang dan rendah. Kategorisasi tinggi, sedang dan rendah dilakukan menggunakan perhitungan quartil. Dan subjek yang akan diambil siswa yang mempunyai kebiasaan menonon film sinetron 
tinggi khususnya tentang tema percintaan remaja dan bertendensi negatif. Quartil adalah membagi suatu distribusi frekuensi menjadi 4 bagian yang sama, sehingga nilainilai dalam distribusi dapat dibagi menjadi K1, K2, K3, (Noegroho, 2012: 118).

Sebelum dan sesudah eksperimen dilakukan beberapa varian yang dikontrol adalah internal varian dan eksternal varian. Menurut Arikunto (2013: 349), untuk menganalisis hasil eksperimen yang menggunakan pre-test dan post-test one group design. Untuk menguji hipotesis di atas dengan taraf nyata $\alpha$ $=0,01$ atau $\alpha=0,05$.

\section{HASIL PENELITIAN DAN PEMBAHASAN}

Berdasarkan dari data dan hasil uji hipotesis, telah diketahui bahwa bimbingan kelompok teknik disksui berpengaruh terhadap mengurangi kebiasaan menonton film sinetron khususnya tentang tema percintaan remaja dan bertendensi negatif di kelas VIII-6 SMP Negeri I Batang Kuis. Hal ini berarti bahwa bimbingan kelompok teknik diskusi dapat direkomendasi dilaksanakan oleh guru BK dalam upaya mengurangi kebiasaan menonton film sinetron khususnya tentang tema percintaan remaja dan bertendensi negatif di sekolah. Di samping itu pengujian hipotesis dilakukan dengan perhitungan uji t. Dari hasil perhitungan diperoleh $t_{\text {hitung }}=15,53$ untuk responden sebanyak 9 orang diperoleh $t_{\text {tabel }}=2,306$. Sesuai dengan kriteria penerimaan dan penolakan hipotesis, tampak $t_{\text {hitung }}>t_{\text {tabel. }}$. Maka hipotesis alternatif (Hi) yang diajukan pada taraf signifikan $0,05 \%$ diterima., diketahui bahwa mengurangi kebiasaan menonton film sinetron khususnya tentang tema percintaan remaja dan bertendensi negatif meningkat dari sebelum kesesudah pemberian layanan Bimbingan Kelompok teknik diskusi. Dengan demikian beberapa hasil penelitian sebelumnya dapat disimpulkan bahwa penelitian ini secara nyata menunjukkan bahwa pemberian Bimbingan kelompok teknik diskusi dalam penelitian ini dapat mengurangi kebiasaan menonton film sinetron khususnya tentang tema percintaan remaja dan bertendensi negatif pada siswa. 
Pengujian hipotesis dilakukan dengan perhitungan uji t. Dari hasil perhitungan diperoleh Harga $t_{\text {tabel }}$ pada $\mathrm{N}-1=9-1$ pada taraf nyata $\alpha-$ 0,05 diperoleh 2,306 , maka $t_{\text {hitung }}>$ $\mathrm{t}_{\text {tabel }}=15,53>2,306$, maka hipotesis yang menyatakan adanya pengaruh yang signifikan antara pelaksanaa layanan bimbingan kelompok teknik diskusi terhadap kebiasaan menonton film sinetron khususnya tentang tema percintaan remaja remaja dan bertendensi negatif pada siswa kelas VIII-6 di SMP Negeri I Batang Kuis dapat diterima. Perhitungan selanjutnya lihat pada

Dengan demikian dinyatakan bimbingan kelompok teknik diskusi mengurangi kebiasaan menonton film sinetron khususnya tentang tema percintaan remaja remaja dan bertendensi negatif di kelas VIII-6 SMP Negeri I Batang Kuis. Perolehan skor rata-rata bimbingan kelompok teknik diskusi dalam mengurangi kebiasaan menonton film sinetron pada saat pre-test $=$ 48,8 . Sedangkan setelah diberi bimbingan kelompok teknik problem solving meminimalisir kecemasan siswa dalam perencanaan karir ratarata post testnya $=64,1$.

\section{PENUTUP}

Berdasarkan hasil penelitian yang diperoleh peneliti, maka dapat disimpulkan bahwa ada pengaruh yang signifikan dari pemberian layanan bimbingan kelompok teknik diskusi terhadap mengurangi kebiasaan menonton film sinetron khususnya tentang tema percintaan remaja dan bertendensi negatif pada siswa kelas VIII-6 SMP Negeri I batang kuis. Hasil perhitungan diperoleh harga $t_{\text {hitung }}>t_{\text {tabel }}=(15,53$ $>$ 2,306), maka hipotesa yang menyatakan layanan bimbingan kelompok teknik diskusi berpengaruh terhadap mengurangi kebiasaan menonton film Sinetron khususnya yang bertema percintaan remaja dan bertendensi negatif pada siswa di kelas VIII-6 SMP Negeri I Batang Kuis diterima.

Berdasarkan kesimpulan hasil penelitian yang telah dikemukakan, maka dikemukakan beberapa saran sebagai berikut: Bagi siswa sebagai pengalaman mengikuti layanan bimbingan kelompok teknik diskusi agar lebih bisa mengurangi kebiasaan menonton film sinetron khususnya yang bertemakan percintaan remaja dan bertendensi negatif. Bagi guru 
BK, diharapkan menggunakan layanan bimbingan kelompok teknik diskusi sebagai salah satu upaya mengurangi kebiasaan menonton film sinetron khususnya yang bertemakan percintaan remaja dan bertendensi negatif. Bagi peneliti lain, sebagai wadah untuk menambah pengalaman, hasanah ilmu pengetahuan dan wawasan yang lebih luas.

\section{DAFTAR PUSTAKA}

Ardlz. 2008. Sinetron Yang

Semakin Tidak Mendidik. [Online] Tersedia: http://rsetiawan.freehostia.co $\mathrm{m} /$ sinetron-yangsemakintidak-mendidik/

Arikunto,Suharsimi. 2010. Prosedur penelitian suatu pendekatan praktik. Jakarta: RinekaCipta.

Dudung. 2005. "Bersekolah" di

Sinetron Remaja. [Online] Tersedia.http://www.dudung. net/buletin gaul (Edisi234) islam/bersekolah di sinetronremaja 209.85.175.104/

Farindra. 2008. Sinetron Modern, Potret Kemunduran Bangsa Indonesia? [Online] Tersedia: http://www.aeonity.com/farin dra.

Hurlock, E. B. (1999). Psikologi
Kehidupan. Edisi 5. Jakarta: Erlangga.

Prayitno. 1995. Layanan Bimbingan dan Konseling Kelompok. Jakarta: Ghalia Indonesia.

Prayitno, dkk. 1994. Dasar-Dasar Bimbingan dan Konseling. Jakarta: Rineka Cipta.

Sumartono,Tono. Dampak Tayangan Televisi Terhadap Perilaku Anak.[Online] Tersedia: http://sumartono.com/dampak -tayangan-televisiterhadapperilakuanak\%20/admin. 